\title{
Emerging International Security Threat: US-Russia Competition
}

\author{
Yang Zairan ${ }^{1}$, Wang Junran ${ }^{2}$, Zhu Kehan ${ }^{3}$ \\ ${ }^{1}$ Beijing Academy, No.7 Dongba Street, Chaoyang District, Beijing 100018, China \\ ${ }^{2}$ Beijing Royal School, No.11, Wangfu Street, Beiqi Town, Changping District, Beijing, China \\ ${ }^{3}$ King's College School Hangzhou, No.1 Guowen Road, Yuhang District, Hangzhou, China
}

\begin{abstract}
This article analyzes the rival of superpowers--U.S.- Russia. and U.S.- China, compare the relationship and probability of escalation conflicts between these two superpowers. The U.S.- Russia relation is analyzed by looking through regional conflicts in the Middle East and Eastern Europe and the ideology difference embed in the conflicts. Also, by identifying the probability of escalation to larger discords between the US and China, the relation between U.S.-China is expanded clearly. By comparing these two superpower relations, we conclude that the probability of the escalation of the tensions is more likely to happen in the U.S.-Russia case compare to the U.S.-China relation. This article ends with policy recommendations to each nation in avoiding conflicts and developing more peaceful relations between superpowers.
\end{abstract}

Keywords: Superpower rivals, the U.S.-Russia relationship, the U.S.-China relation, regional conflicts, Eastern Europe

\section{INTRODUCTION}

The unprecedented economic growth in the 21 st century could be largely attributed to a relatively peaceful international order, following the collapse of the bipolar order. However, several emerging conflicts have threatened international security, rendering the existing peace more and more fragile.

Even though the participation of the Northern Giant, the USSR, has declined since the 1980s, its successor, Russia Federation, has not abandoned the desire of expansion. The expansions are best depicted by regional conflicts, as recognized by Doctor Muhammed Ayoob's article, "The Third World Security Predicament: State Making, Regional Conflict, and the International System." [1] In another sense, China has become increasingly important in international order. With ultimate potentials in the economic burgeoning, China has never quit pursuing economic opportunities, as mentioned in Doctor Robert S. Ross's article, "A Realistic Policy for Managing US-China Competition." [2] With multiple analysis, scholars have identified regional conflicts as the playgrounds for powers. However, the prediction of future development of liberal order requires scholars to distinguish the difference between the US-Russia and US-China relations. The foundational interests of the two entanglements need to be concluded and compared to foresee the key clashes and policy orientations as the nations must make trade-offs between their tactics. Hence, in complementing the precedent articles, this essay approaches the problem with an inclusive analysis of the interests in regional situations with two distinctive areas, Eastern Europe and the Middle East, while identifying the probability of evolution to larger discords between the US and China. Then compares the probability of the escalation of the tensions and ends with considerable policy recommendations to individual nations regarding the development of more peaceful, or balanced, relations in the future.

\section{US-RUSSIA COMPETITION UNDER REGIONAL CONFLICTS}

US and Russia support different and often opposite sides in the 21 st-century wars. The region can be seen as a turbine, while its outcomes are exploited by the great powers, it is still generating heat internally. It is worth noting that the great powers often target the middle east and central Asia as their playground. Indeed, numerous reasons account for this phenomenon, and the factors are both homogeneous and heterogeneous.

\subsection{The Middle East}

The United States is bound to a seemingly unnoticeable area on the map and is constantly supporting the nations in the region. There must be factors of substantial importance that tempt the US to participate in the conflicts. First, the Middle East is a curial resource repository with significant economic implications. Crude Oil is largely based beneath the Middle East Continent. If the resources are lost to the hands of its rivals, the US will soon face oil crises and economic stagnation. Hence, the US desperately wants to control its arteries. [3] Moreover, there are strategic and anti-terrorist concerns. Israel is one of the most important allies for the US. The US would try its best to prevent possible assaults against Israel, especially nuclear 
proliferation. Additionally, the state builder dilemma is the most serious risk for expanding influence. While the US acknowledges that a central government is vital to antiterrorism, the government must be established within the control of the US with an unbreakable economic and military link [4].

Indeed, Russia did not acquire a head start at the beginning of this century due to the terrible economic policy in the CIS. Yet, with adequate ruling policies, Russia's resurgence is inevitable. Three major factors contribute to the participation of Russia: Domestic secessionism, economic opportunities, and geopolitical considerations. Secessionist forces are the strongest on the southern border, with radical separatists and potentially intensified Muslims. Economic opportunity includes oil, but also trading opportunities and markets are needed to satisfy this rising power. As for geopolitical consideration, as the US dominates the western hemisphere, Russia should balance this with its control over Central Asia and focuses on its global credential. However, the state builder's dilemma also applies to Russia [5].

Several conflicts characterize current US-Russia relations. First, the US and Russia would try various methods to gain control of oil. Both nations would persuade the nations by providing military protection and economic support. To take down their rivals, they utilize proxy wars and the media. Another dispute is about regional security and balance of powers. They both recognize that if one side dominates the region, it would break the current equilibrium. Thus, each fight hard to prevent the growing power of the other while promoting its own domination. The third conflict is about the threat to the domestic scheme. Russia wants to take control of Georgia for domestic secessionism while NATO power expands to it. US has its ally Turkey entangled with Russia's issue, rendering the US unable to create another outpost in the Middle East. Hence, the US would banish Russia's support by sanction.

However, there is still room for collaborations, notably in countering terrorism and extremists with military intervention from both great powers. Yet, it leads to further entanglements related to religion and ethnic conflicts such as Kurd's affairs.

\subsection{Ukraine Crisis}

Constant conflicts in Eastern Europe are also revealed in the U.S.-Russia competition. An abundance of evidence - the cyberwar against Estonia in 2007, and the August 2008 invasion of Georgia - reflect Russia's determination to reestablish its regional superiority and status as a global power. The most influential conflict between the U.S. and Russia is the Ukraine Crisis which ended with the Russian military intervention. The Ukraine Crisis is a symbolic representation of the competition between the U.S. and Russia. By looking through the factors that cause Ukraine crises, people can gain an insight on the in-depth conflict between the U.S. and Russia.

First of all, the ideological difference between the U.S. and Russia is the fundamental cause of the Ukraine Crisis and the contest of these two countries in Europe. Putin holds the realism perspective that great power is always sensitive to potential threats near their home territory. Russia has been arguing against the eastward enlargement of Western power since the mid-1990s. However, the U.S. - overtaken by liberalism together with the convinced European countries - aim to pursue their liberal idea to the entire continent and make them look like western Europe. Believing that geopolitics no longer matters, and allinclusive liberal order could maintain peace in Europe, the Westerners support the enlargement of the EU and NATO. The tendency of the alliance between the US and Ukraine unknowingly threatened Russia and provoked it to act out. Moreover, this ideology difference is a long-term problem that constantly causes the U.S.-Russia conflicts in Europe since neither of them is willing to compromise and change their perspective. Russia insists to pursue its leading role in Eastern Europe so that it can determine the fate of countries in the region [6]. This ideology difference between realism and liberalism is a significant factor of the outbreak of the Ukraine Crisis and also the potential reason for the outbreak of later conflict in Europe.

Secondly, Russia's standpoint is the main cause of the Ukraine Crisis. After the collapse of the Soviet Union, Russia is still in the quest of self-cognition. But there is an agreement among the political elites to keep Russia as a global leader, aiming at multipolarity. Moreover, to maintain the dignity of a superpower, Russia is willing to sacrifice its economic relation with the West to protect its zone privileged interest. Russia intervenes in the Ukraine Crisis basically to reassert its dominant status in the former Soviet territory. It views the expansion of the EU and NATO a harm to its superpower dignity. As a response to Russia's meddling in Ukraine, the West, led by the U.S., has imposed economic sanctions on Russia. In July 2014, the U.S. and the EU validified their 3rd round sanction, targeting banks, energy companies, and defense firms, also threatening to put sanctions on the whole Russian economy [7]. Hence, these harsh sanctions did not affect the decisions of Russia but exacerbate the relation between the U.S. and Russia. Getting out of Ukraine Crisis and view the U.S.Russia relation in a broader view, Russia's vision of international relations causes it to view itself as a global leader while seeing the expansion of pro-Western attitude in Eastern Europe as a threat. The standpoint of Russia contrasts with the U.S.'s view that America is the only hyperpower.

Finally, the difference in political agendas between Eastern European nations and Russia also accounts for the Ukraine Crisis. Eastern European nations want to join the EU to boost the economy. For Ukraine, the pro-Western attitude is more beneficial for the country's development. However, Russia generates pressure on Ukraine that provokes the eagerness of Ukraine to join NATO. This further irritates Russia, eventually resulting in the invasion of Ukraine. Not only for the Ukraine Crisis but also for other countries in Eastern Europe, there is no option besides cooperating with the EU to become a highly open and internationally competitive economy [8]. Russia, considering this as a threat to its own national interests and status as a global leader, generated pressure to those countries. With the 
U.S.'s support and the spread of liberalism, citizens in Eastern Europe go against Russia and believe that the U.S. would come to their aid. There is an inevitable conflict between Eastern European countries' natural urge to develop and Russia's decision to protecting its territory right and superpower dignity. Even worse, for western countries, it is their obligation to help the eastern European countries to be consistent with the human rights propaganda, but they are not willing to provide military support to those Eastern European countries. Therefore, Eastern European countries' liberal beliefs that countries have the right to self-determination, and the naive conviction that the U.S. is willing to offer military support, conflicted with Russia's own benefits and power.

\section{FORESEE OF US-CHINA RELATION FROM A PESSIMISM VIEW}

Nowadays, US-China relation is far beyond steady, Although the relation between the two countries is very complicated, the conflicts between them are not particularly intense.

The world today is monopolar, while America is the only hegemon. According to the theory of Thucydides Trap, when a rising power has confronted a ruling power, the result has been bloodshed [9]. The rapid economic developments in China generate substantial power, so neighboring countries feel threatened. They would like to collaborate with the US to prevent China from being too powerful [10]. However, overreaction to the rise of China may lead to unnecessary wars. The US already has overreacted to the growth in China, trying to keep military superiority in the world. If the rivalry between China and the United States continues to grow, the occasional skirmishes can quickly escalate into major confrontations and even wars.

\section{US-RUSSIA RELATION IS MORE INTENSE THAN US-CHINA RELATION}

First, the security dilemma is greatly mitigated by geographical locations and nuclear weapons of the US and China. China and America are separated by the vast expanse of the Pacific Ocean, where large-scale attacks are hard to happen. Also, both of the countries have advance nuclear weapons, which makes it relatively easy for major powers to maintain highly effective deterrent forces [11].

Second, China and America are important trading partners, so it is not easy to break that bound. The commercial ties between the two countries can often prevent conflicts. In China-US relations, economic and trade relations have long been regarded as the "ballast". As the world's two biggest economies, China and the United States could significantly worsen global economic growth in the event of an intense trade conflict. Reducing or increasing the trade status of either party may change the face of the international economy. For this reason, it is not enough to discuss trade frictions only from the bilateral perspective. It is necessary to examine the profound impact of trade frictions between China and the United States from the perspective of regional and international systems. In order to keep the international economic stability, economic cooperation between China and the United States is essential.

Third, a Cold War between China and the US is unlikely because the background of the contemporary world is very different from the last century. Nowadays, the world is unipolar. Asia is more polarized than Europe during the Cold War. It can not only be dominated by China and the United States, but also by other powers, such as Russia. China and the United States are now fighting for sovereignty instead of domination, while other countries will still be significantly competitive in certain areas. The uncertainty created by the multipolar environment has kept the rivalry between China and the United States from reaching the intensity of war.

China and the US are less likely to have a war and the conflicts between them are not that intense as between Russia and the US. Although the historical trends between the development of the two great powers are usually war, the future of China-US relations is determined by the people of China and the United States.

On the other hand, we must see US-Russia Competition as more likely to escalate and become more a threat to the liberal order of the world.

In the Middle East Issue, Russia's economic resurgence would increase the tension of economic interest, as well as its military power. Thus, the regional balance would shift, and the US will be further suppressed. The US has foreseen the potential of Russia while having to constrain China. Facing two sides, the US might loosen the control of the Middle East. At that time, the US would be forced to put more investment in this conflict, potentially upgrading it. Third, the region has intensified religious conflict and demands more military support. A world war is not likely to occur, but numerous proxy wars are expected. Fourth, the international reputation of the nations would face up and downs due to the state builder dilemma, and both nations would have to take bolder actions in gaining influences. Sixth, both sides have unconsciously agreed to prevent the emergence of the third great power, which would be easily created in the breeding ground of Central Asia if no conflict exists; hence US and Russia will still maintain this conflict and balance within years to come [12].

For the Ukraine Crisis, the U.S.-Russia conflict will constantly happen in Europe caused by their ideology difference. This is not only a threat to the relation between the U.S. and Russia, which economic sanctions and political blames occur, but also a threat that disturbs the economic and citizens' well-being in Eastern-Europe countries. The protests, political threats, revolutions, and even casualties in Eastern-Europe countries have become sacrifices in the U.S. and Russia competition. So, the U.S.- Russia contest is not only harmful to their own economics but also a threat to the welling-being of Eastern European countries. 


\section{POLICY RECOMMENDATIONS}

\subsection{Liberalism respective}

The structural conflict between U.S. and Russia can be relieved and even solved by the change of ideology of Russia and the abandonment of intention of radical expansion from the U.S.; these two countries can sort out a balance in their relations. Only without the violation of the "sphere of privileged interests" for Russia and the belief of a win-win situation between these two countries can generate a peaceful and mutually beneficial relationship.

\subsection{Realism Perspective}

Russia needs to acknowledge that a balanced situation is better than the regional hegemon. Russia would first reinforce its advantage by firmly supporting the proRussian states. For example, absolute support of the Assad government. Although this will arouse more disagreements, Russia will gain more sturdy allies. Then, maintain the entanglements with NATO, which means creating military tension while maintaining economic relations, such as Turkey, forcing them to have reservations about taking sides. Finally, Russia could encourage anti-US propaganda and uncompromising diplomacy while promoting agreements with the US underground, stalling the situation until the US proposes adequate offers.

The US has to maintain its current interests while gaining more opportunities. Since the US has a better start than Russia, the US should focus on indirect interference and propaganda. Maintain the economic and military domination over NATO nations, especially Turkey. This would create strong oppression towards Russia. Then, avoid direct military contact in case of escalation. US should have reservations about its foreign military camps: a better substitute can be other NATO nations' army since the US army is losing its reputation. The US should gain a better reputation by not only supporting the government but also the citizens. The US should also be cautious with the nations they support, especially when it comes to religious nations. Above all, the US should force Russia to compromise, stalling the situation until Russia comes up with satisfying terms.

\section{CONCLUSION}

Many people adhere to the idea that a war between the US and China is inevitable, according to the theory of Thucydides Trap, US's hegemony position in the world, and overreaction of other countries. However, the relation between Russia and the United States is more intense than the relations between the United States and China. Nuclear weapons and geographical locations, cooperation in trade, the unipolar trend of the world, and necessary future collaboration suppress the possibility of war, while the US and Russia are less likely to maintain peace because of their ideological difference and escalating interest clashes. We warn the leaders to focus on the policy recommendations to construct a balanced world.

US-Russian competition is a chronological threat to the liberal order, yet the threat is dissimilar in different trends. While liberalists believe a security dilemma can be avoided under constructed peaceful alliances, realists point out only a balance of power can establish stabilized relations with self-security guaranteed. This paper crosses the barriers between realism and liberalism. Further expansion of the researches based on the competition can be more detailed when solely focus on realism or liberalism.

This paper only concludes a trend of competition with few cases of analysis, which specify those regions. Other regions may apply to the general trend but vary specifically. Further cases can be solely discussed in detail. Only with nations who have scrutinized and balanced the interests can they accept profitable policies.

\section{REFERENCES}

[1] Ayoob, Mohammed. The third world security predicament: State making, regional conflict, and the international system. L. Rienner Publishers, 1995.

[2] Ross, S. Robert. "A Realist Policy for Managing USChina Competition." Policy Analysis Brief, 2005.

[3] Nichol, Jim. "Central Asia: Regional Developments and Implications for US Interests." LIBRARY OF CONGRESS WASHINGTON DC CONGRESSIONAL RESEARCH SERVICE, 2010.

[4] Byman, Daniel, and Sara Bjerg Moller. "The United States and the Middle East: Interests, Risks, and Costs." J. Suri, \& B. Valentino, Sustainable Security: Rethinking American National Security Strategy, 2016, pp.263-309.

[5] Dannreuther, Roland. "Russia and the Middle East: A cold war paradigm?." Europe-Asia Studies 64.3, 2012, pp.543-560.

[6] Mearsheimer, J. John. "Why the Ukraine crisis is the West's fault: the liberal delusions that provoked Putin." Foreign Aff. 93, 2014, pp.77.

[7] Nováky, Niklas IM. "Why so soft? The European union in Ukraine." Contemporary Security Policy 36.2, 2015, pp.244-266.

[8] Christie, Edward Hunter. "The design and impact of Western economic sanctions against Russia." The RUSI Journal 161.3, 2016, pp.52-64.

[9] A. Grahan, "The Thucydides trap: Are the US and China Headed for war." Retrieved Set 24, 2015. 
[10] Mearsheimer, J. John. The tragedy of great power politics. WW Norton \& Company, 2001.

[11] Glaser, Charles. "Will China's rise lead to war? Why realism does not mean pessimism." Foreign Affairs, 2011, pp.80-91.

[12] Rumer, B. Eugene, Dmitrĭ Trenin, and H.S. Zhao. Central Asia: Views from Washington, Moscow, and Beijing. ME Sharpe, 2007. 